\title{
新型コロナウイルス感染症による活動制限が理学療法 学科学部生に扔ける大学生活の不安感に及ぼす影響
}

——授業，臨床実習，就職活動に着目した報告——

\author{
Effect of Activity Restrictions Imposed by COVID-19 on the Anxiety Level \\ of Physical Therapy Students: A Report Focusing on Lessons, Clinical Training, and \\ Job-hunting Activities
}

広瀬 環 ${ }^{1,2}$ 屋嘉比 章紘 ${ }^{1)}$ 小野田 公 ${ }^{1)}$ 久保 晃 ${ }^{1)}$

TAMAKI HIROSE, RPT ${ }^{1,2)}$, AKIHIRo YAKABI, RPT, PhD $^{1)}$, Ko ONODA, RPT, PhD ${ }^{1)}$, AKIRA KUBO, RPT, PhD ${ }^{1)}$

1) Department of Physical Therapy, School of Health Sciences, International University of Health and Welfare: 2600-1

Kitakanemaru, Ohtawara-shi, Tochigi 324-8501, Japan TEL+81 287-24-3018 E-mail: n-tamaki@iuhw.ac.jp

2) Department of Health Sciences, Health and Welfare Education and Management, Graduate School of Health and Welfare, International University of Health and Welfare

Rigakuryoho Kagaku 35(6): 911-915, 2020. Submitted Jul. 1, 2020. Accepted Aug. 19, 2020.

\begin{abstract}
Purpose] To ascertain the degree of anxiety experienced by physical therapy students in their college life owing to activity restrictions imposed by the COVID-19 pandemic. [Participants and Methods] To investigate the anxiety level, we conducted an online questionnaire survey of 377 1st to 4th-year students belonging to the Faculty of Physical Therapy, International University of Health and Welfare, Otawara, Tochigi, Japan. [Results] The median anxiety scores were found to be 7-8 for all items. Upon comparison, job hunting activity was significantly higher among the 3rd and 4th graders than among the 1st and 2nd graders. Besides, practical training was observed to be significantly higher among the third graders than in any other group of students. In the practical skills class, both the 2nd and 3rd graders had significantly higher involvement than the 1st and 4th graders. [Conclusion] It was shown that the restriction of activities imposed by COVID-19 is a significant factor causing anxiety among physical therapy students during the course of their college life.
\end{abstract}

Key words: COVID-19, undergraduate physical therapy students, anxiety

要旨：〔目的〕新型コロナウイルス感染症による活動制限が理学療法学科学部生の大学生活に及ぼす不安感の程度を 明らかにすること。【対象と方法〕国際医療福祉大学理学療法学科学部生 377 名を対象に, Web 上アンケートを作成 し, 不安感の調査を行った。〔結果〕全ての項目において不安感の中央值は 7〜8 となった. 各学年比較では, 就職活 動は 3，4 年生いずれも，1，2 年生それぞれと比較して有意に高值となった。実習は 3 年生がどの学生よりも有意に 高值となった．実技系授業は $2 ， 3$ 年生いずれも，1，4 年生それぞれと比較して有意に高値となった。〔結語〕新型 コロナウイルス感染症による活動制限は理学療法学科学部生の大学生活において, 不安感を抱く要因となっているこ とが示された。

キ一ワード : 新型コロナウイルス感染症, 理学療法学科学部生, 不安感

\footnotetext{
1) 国際医療福祉大学 保健医療学部 理学療法学科：栃木県大田原市北金丸2600-1 ( T 324-8501)

TEL 0287-24-3018

2) 国際医療福祉大学大学院医療福祉学研究科 保健医療学専攻 医療福祉教育・管理分野

受付日 2020 年 7 月 1 日 受理日 2020 年 8 月 19 日
} 


\section{I. はじめに}

世界で感染が拡大している新型コロナウイルス感染症 （以下，COVID-19）の影響により，2020 年 4 月 7 日, 日本政府から緊急事態宣言が 7 都府県に，4月 16 日に 全国に発令された 1). COVID-19 対策として，手洗い. うがい・咳エチケットの励行とマスクの着用, 密集・密 閉・密接の 3 密を避けることを目的とした, 小中高校・ 大学の休校や分散登校, 在宅勤務, 外出自肃, 大規模个 ベント等の自肃, 繁華街の接待を伴う飲食店等（ジムや カラオケの娛楽施設等を含む）の営業自粛など, 2020 年 2 月より感染拡大状況に合わせた様々な対策が推奨さ れている 2,3)

本学でも，4月20日より全学生に対しキャンパスへ の立ち入りが禁止となった。 それに伴い，授業開始時期 の延期やオリエンテーションを含む授業をすべてオンラ イン授業へ移行し, 新年度が開始した状態である。オン ライン授業は，双方向を確立した配信型授業にて遠隔授 業を行っている. そのような状況のなかで, 学生は大学 生活において多くの不安を抱えていると考える.

理学療法学科学部生を対象にした不安感の先行研究で は, 大学生活 4-8), 臨床実習 9,10)に対する調査が行われ ている。また, 各学年において学習および生活満足度に 変化があることや臨床実習等の経験が学習意欲や知識, 就職活動へ影響することが示されている 11-17).

COVID-19 に対するアンケート調査において LINE 社 は，全体の $84 \%$ が不安であるとし，民間企業は，不安 の変化や不安要因について報告している18,19)。また, 他大学においても COVID-19への感染や就職活動に対 する不安調査が行われている 20,21)。さらに，社会人や 農大生を対象にしたメンタルヘルスの調査報告があ る22,23).このようにCOVID-19に対するアンケート調 査は散見されるが, 理学療法学科学部生を対象にした調 査報告は確認できていない。本学理学療法学科は, 進級 に伴い実技系授業が増加することや，各学年に実習が組 み达まれるなど, 固有のカリキュラムで構成されてい る24)。また, 就職活動の時期が 4 年次の臨床実習終了 後に開始することも特徵的である. そのため, 授業や臨 床実習, 就職活動に対する不安感の程度に違いがあるの ではないかと考えた

そこで，本研究の目的は，COVID-19による活動制限 が理学療法学科学部生の大学生活における不安感の程度 を明らかにするため，大学生活における授業，臨床実習， 就職活動に着目して調査することとした。また，今回の 調査は横断的研究の結果であり, 縦断的な研究の第一報 として報告する。

\section{II. 対象と方法}

\section{1. 対象}

対象は 2020 年 4 月, 理学療法学科学部生 $1 \sim 4$ 年生 の全 398 名, アンケートを実施し, 期間内に回答が得 られた 377 名（回答率 $94.7 \%, 4$ 年生 86 名, 3 年生 94 名, 2 年生 100 名, 1 年生 97 名, 男性 210 名, 女性 167 名), 年齢 $19.7 \pm 1.8$ 歳（平均 \pm 標準偏差）とした。実施に あたり全対象者に調査実施に関する説明を書面にて行い 参加の同意を得た。なお，本研究は国際医療福祉大学倫 理審査委員会の承認を得て行った（承認番号：20-Io30).

\section{2. 方法}

アンケート調査は, Web 上にて Google フォームを使 用したアンケートを作成し，全国に緊急事態宣言が発令 されたのちの 2020 年 4 月 22 日〜24日の 3 日間で行った。 不安感に対する項目を「COVID-19に対する不安感」(以 下, (1) COVID-19), 「就職活動に対する不安感」（以下 (2)就活)，「今後の実習に対する不安感」(以下，(3)実習) 「今後の実技系授業に対する不安感（実技系授業に対す るリスク等)」(以下，(4)実技系授業)，「今後の実技系授 業がなくなる可能性に対する不安感」（以下，(5)実技系 授業なし), 「学習に対する不安感」(以下, (6)学習) の 6 項目で構成した。 10 段階評価（1：まったく不安を感 じない, 10：とても不安である）で, 不安感の程度を 選択する形とした，回答は必須ではなく，任意としてア ンケートを実施した，回答の最後には，「何か不安に思っ ていること等があれば自由に記載してください」とし, 自由記載の回答欄を設け, 就職活動, 学習面（授業, 実 習), 生活面, その他で分類した.

統計解析は, 全項目間の此較を全体, 男女別に Friedman 検定で行い，下位検定として Bonferroni の補 正を行った．各項目の男女間比較を Mann-Whitneyの U 検定を用いた，学年ごとの比較を Kruskal-Wallis 検定で 行い，下位検定としてBonferroni の補正を行った。下 位検定 Bonferroni の補正の有意水準は $0.3 \%, 0.8 \%$ とし それ以外は全て 5\%とした。なお，解析ソフトは, SPSS Statistics ver. 25 (IBM 社製) を使用した.

\section{III. 結 果}

全対象者の全項目に対する不安感を, 中央值（第 1 四 分位数一第 3 四分位数) で示す（表 1). 全体では, (1) 「COVID-19」8（7-9），(2)「就活」8（6-9)，(3)「実習」 7 （5-8），(4)「実技系授業」8（7-10)，（5)「実技系授業 なし」8（7-10） (6)「学習」8（7-10）となった. その なかでも，(5)「実技系授業なし」，(6)「学習」に対する 不安感が, (2)「就活」, (3)「実習」, (4)「実技系授業」と 
表 1 全項目における全体の不安感

\begin{tabular}{cccccccc}
\hline & (1) COVID-19 & (2)就活 & (3)実習 & (4)実技授業 & (5)実技授業なし & (6)学習 \\
\hline 全体 & $8(7-9)$ & $8(6-9)$ & $8(6-9)$ & $7(5-8) * \dagger+$ & $8(7-10) \dagger \ddagger \S$ & $8(7-10) \dagger+\S$ \\
\hline
\end{tabular}

中央值（第 1 四分位数 - 第 3 四分位数）．COVID-19：新型コロナウイルス感染症， p < 0.003。*：vs (1)，†：vs (2)，末： vs (3), § : vs (4).

表 2 各項目における各学年比較

\begin{tabular}{lclllll}
\hline & 1) COVID-19 & (2)就活 & (3)実習 & (4)実技授業 & (5)実技授業なし & (6)学習 \\
\hline 1 年生 & $8(6-8)$ & $6(5-8)$ & $7(6-8)$ & $6(5-7)$ & $8(7-9)$ & $8(7-10)$ \\
2 年生 & $8(7-9)$ & $7(5-8)$ & $8(7-8.75)$ & $7(6-8) \ddagger$ & $8(7-10)$ & $8(7-9)$ \\
3 年生 & $8(7-10)$ & $8(7-9) \dagger 末$ & $8(7-10) \dagger \ddagger$ & $7(6-9) \ddagger$ & $9(7-10)$ & $8(7-9.75)$ \\
4 年生 & $8(7-9)$ & $8(8-10) \dagger \ddagger$ & $7(5-8) *$ & $5(4-7) * \dagger$ & $8(6-10)$ & $8(6-10)$ \\
\hline
\end{tabular}

中央值 (第 1 四分位数 - 第 3 四分位数). COVID-19：新型コロナウイルス感染症. p < $0.008 . *$ : vs 3 年, †: vs2 年, 未: vs1 年.

比較すると有意差があった，各項目の男女比較では，有 意差は認めなかった

各学年比較では, (2)「就活」は 3, 4 年生いずれも, 1 , 2 年生それぞれと比較して有意に高值となった。(3)「実 習」は, 3 年生がどの学年よりも有意に高值を示した。 (4)「実技系授業」は2，3 年生いずれも，1，4 年生それ ぞれと比較して有意に高值となった（表 2). 自由記載 の内容について, 4 年生は就職活動, 学習面 (特に実習) の不安に関する内容が 11 件, 1 年生は学習面の不安に 関する内容が 8 件あり, 特にオンライン授業による学習 への影響や機器操作に関する内容が多数であった。

\section{IV. 考 察}

COVID-19による活動制限が理学療法学科学部生の大 学生活に与える不安感の程度について明らかにするため, 国際医療福祉大学保健医療学部理学療法学科学部生を対 象にWeb 上にて不安感のアンケート調査を行った。

結果より, 全項目に対する不安感の中央值が 7〜8 なった，COVID-19 拡大により，大学への登校制限や例 年と異なった形式で新年度が開始したことが要因である と考える。また，(1)「COVID-19」，(2)「就活」におけ る不安感の 10 段階評価から，6〜10 を不安感が強いと した場合，その割合は，(1)「COVID-19」が88.3\%，(2) 「就活」が79.6\%であった。これらは，全国民を対象に した不安感調査の同世代の結果や, 他大学の COVID-19 および就職活動に対する不安感の結果と同様であったと 考える18,20,21). さらに, (5)「実技系授業なし」, (6)「学習」 において有意差があった理由としては, COVID-19の影 響により，すべての授業がオンライン授業という新たな 形式になったことが一要因と考える。それに伴い，実技
系授業がなくなる可能性が容易に想像でき，技術習得の 遅延や，臨床実習等への影響を及ぼす可能性があること から，(5)「実技系授業なし」への不安感につながったと 推察する。

各学年比較の結果より, (2)「就活」で 3, 4 年生いず れも，下位学年との比較で有意差が認められた理由とし ては, 就職活動に年齢・学年が近いほど不安感が強くな ると考える。民間企業が行ったCOVID-19 拡大時の就 職活動調査 ${ }^{25)}$ では, 大学 3 年生の $83.5 \%$ が就職活動に 不安があるとされており, 本研究の結果も同様となっ た. そのなかで, 本研究対象者の特徴として, 4 年次の 臨床実習終了後に就職活動が開始となる。しかし, 今年 度はCOVID-19の影響により，臨床実習施設での受け 入れが中止または延期となった学生も多く, 今後の実習 再開見込みについても定まっていない状況である。就職 活動については, 内定先応募のきっかけとして実習施設 が一因子として挙げられている13)。 また, 就職活動不 安の一因子に準備不足があることが報告されている 26). 臨床実習の中止や延期は臨床実習経験が不足し, 就職活 動に対する準備不足が示唆され, さらに臨床実習終了時 期が遅延すると, 就職活動に影響を与えるため, それら の要因から不安感増大につながったと考える。実際に, 自由記載において, 4 年生からは「就職が不安」,「実習 がなくなること，遅れることによる就職活動への影響」 と漠然とした就職活動への不安感もある。その一方で, 「次の臨床の機会が就職後であると技術が足りない」, 「実習に行けなくても就職活動に不利にならないか」な ど臨床実習を経験できていないことによる自分自身の知 識や技術面の不足が, 就職活動に対する準備不足につな がり, 不安感が増強する要因になったと考える。また, 全国的に就職説明会が延期や中止となり，就職内定率は, 
2020 年 5 月 ( -5.7 ポイント), 6 月（-13.4 ポイント $)$ と 2 カ月連続で前年同月比を下回った ${ }^{27)}$ 。これらも就 職活動に対する不安感の増強の要因になると考える.

(3)「実習」に関しては，3年生が他学年よりも高值で あった。例年であれば 7 月末からの 3 週間と翌 2 月か らの 12 週間で臨床実習が開始される予定である。通常 時, 臨床実習前に不安感が増大するという報告があり, 先行研究と同様の結果となったと考える ${ }^{8,9}$. そのため, 本研究の結果において, COVID-19による活動制限から 不安感が増大したとは言い切れない。しかしながら, 本 学の現状は，4 年生の臨床実習が中止や延期となり, 実 習状況が不安定である。 3 年生は, これから臨床実習を 控えていることに対する通常時の実習前不安感の増大に 加え, COVID-19による本学の実習状況等によって, 不 安感が高值を示す一要因になったのではないかと考え る。また臨床実習経験は, 理学療法学科学部生における 歩行分析能力の経時的変化に影響を与えることや, 臨床 実習形態の違いがあっても臨床実習経験後に成績が向上 することが報告されている11,12)。このように，臨床実 習経験が学習に影響を与えることも, 不安感が増強する 要因になったと推察する.

(4)「実技系授業」に対する不安感が増大した要因に関 しては, 実技系授業では, 検査・測定や実験等, 学生同 士が実際に直接触れ合って検査・測定の実技練習や実験 等を行う。理学療法士としての検査・測定技術の習得は, 実習を控える学生にとって必要不可欠である。また，例 年通りであれば $50 \sim 100$ 名の学生が一同に会し，1教室 内で授業を行う。それは現在, 感染予防として推奨さて いる 3 密 (密集・密閉・密接) をすべて網羅してしまう 状況であることを, 在学生は容易に想像ができる. COVID-19 の影響により実技系授業が開講されないこと から, 今後の知識, 経験不足などが生じることで, 学習 や実習への不安感につながると考えられる。その結果, 実技系授業が増加する 2,3 年生が有意に高值であった と考える。さらに，4年生は対面授業が少ないこと， 1 年生は実技系授業の情報が少ないことと, 運動学・解剖 学・生理学など基礎医学系の授業が多いことも要因であ ると考える。

学生の不安感を軽減させる一般的な対応策として，リ

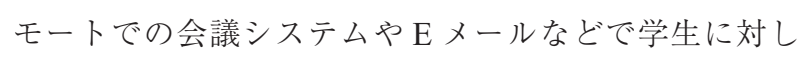
て大学の対応や公的な情報を丁寧に学生に伝える（授業 や実習に関する対応, 経済困難者への経済的支援, 実際 の対策など）ことが考えられる，本研究の結果に対する 対応策として, 就職活動においては, 通常通りの面接指 導に加え, 面接形態変化に合わせた面接方法（オンライ ン面接）の指導, 就職状況についての定期的な学生との 報告, 連絡, 相談が必要であると考える。現状における 本学科の取り組みとして, それらに加え, 就職活動 2 週 前の健康状態確認を行い, 感染拡大防止に努めるととも
に, 就職活動（見学, 書類審査, 面接等）の進行状況の 管理をすべて Google フォームで実施する方法に切り替 える等の対策を行っている。また，実技系授業や実習に おいては, 代替案の構築（ビデオコンテンツの作成, 課 題レポートなど）が考えられる。現状における本学科の

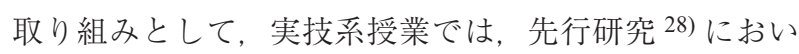
て実用性が示されているデジタル教材を使用した暗記 カードの学習方法の活用や, インターネットを使用した 演習課題を提示し, オンライン上で各学生の課題に対す る指導を行っている.

最後に, 本研究の限界として, アンケートにて不安要 素の項目を提示したため, 学生が考える不安感要因をす べて把握することは困難であった。また，6 項目に対す る不安感の程度のみを評価したため, 各項目に対しどの ような不安を抱いているか, 記述項目を設けることで, より具体的な内容を把握することができると考える。さ らに, オンライン学習に対する不安を抱いている可能性 も考えられるため, 調査を進めていきたいと考える.

今後は, COVID-19による活動制限が, 不安感に与え る影響だけでなく, 活動面や学習面への影響についても 検討していく必要がある。 そのためにも縦断的に評価を 進めていき, 重症感染症の拡大による保健・医療・福祉 系に通う学部生に与える影響を明らかにすることで，今 後の感染症拡大の際の医療系養成校での教育・指導方法 の基礎データが得られると考える。

利益相反 本研究において開示すべき利益相反関係にあ る企業・組織および団体等はない.

謝辞 本研究を実施するうえで調査にご協力頂いた，国 際医療福祉大学保健医療学部理学療法学科の学部生と教 員の皆様に感謝致します.

本研究は, JSPS 科研費（20K23204）の助成を受けた ものである.

\section{引用文献}

1) 内閣官房 : 新型コロナウイルス感染症緊急事態宣言の概要. https://corona.go.jp/news/news_20200421_70.html（閲覽日 2020 年 5 月 27 日).

2) 厚生労働省：新型コロナウイルス感染症対策アドバイザ リーボード, 専門家会議の見解等「新型コロナウイルス感 染症対策の状況分析 · 提言」. https://www.mhlw.go.jp/stf/ seisakunitsuite/bunya/0000121431_00093.html（閲覧日2020 年 7 月 27 日)

3) 内閣官房 : 新型コロナウイルス感染症対策の基本的対処方 針. https://corona.go.jp/news/news_20200411_53.html（閲覧 日 2020 年 7 月 27 日).

4) 佐野徳雄, 廣瀬 昇, 跡見智章・他：理学療法学科におけ る大学生活不安感の経時的変化と学年比較. 帝京科学大学 紀要, 2017, 13: 31-36. 
5) 金子千香, 平林 茂, 菅沼一男·他：理学療法学科 1 年生 に打ける大学生活不安の経時的変化とその対策. 理学療法 科学, 2015, 30: 689-692.

6) 菅沼一男, 平林 茂, 金子千香・他：理学療法学科学生に 扔ける大学生活に対する不安について一学年間比較一。理 学療法科学, 2015, 30: 475-478.

7) 金子千香, 平林 茂, 菅沼一男 - 他 : 理学療法学科新入生 の抱える大学生活不安に関する 2 大学間の比較. 理学療法 科学, 2017, 32: 85-88.

8) 金子千香, 平林 茂, 菅沼一男 - 他：理学療法学科学生の 長期臨床実習による大学生活不安変化について。帝京科学 大学紀要, 2018, 14: 313-317.

9) 濱田浩樹, 橋元孝典, 石塚隆二・他 : 学生が臨床実習直前 に抱く不安要因一CS ポートフォリオ分析の応用一. 理学療 法科学, 2013, 28: 39-43.

10) 木村智子, 松田和郎, 相見良成・他: 理学. 作業療法学科 の学生に対する効率的人体解剖見学実習一その有効性と意 義一. 形態・機能, 2012, 11:24-32.

11) 屋嘉比章紘, 小野田公, 石坂正大・他 : 臨床形態の違いが 国家試験相当の実地問題の成績に与える影響一従来型実習 と診療参加型実習の比較一. 理学療法科学, 2020,35: 367370.

12) 山本裕晃, 松田憲亮, 森田正治: 臨床実習経験は理学療法 学生に扔ける歩行分析能力の経時的変化を与える一Wisconsin Gait Scaleを用いた養成校学生の変化一. 理学療法 科学, 2020,35: 159-163.

13) 石坂正大, 久保 晃, 金子純一朗・他 : 理学療法学部生の 就職先の現状と就職先選定一 3 キャンパスの特徵一. 国際 医療福祉大学学会誌, 2017, 22: 77-82.

14) 久保 晃, 黒沢和生, 丸山仁司：東日本大震災後の理学療 法学科学部生QOL の年次変化一学部 3 年末での学習㧍よ び生活面の満足度から一. 理学療法科学, 2014, 29: 10071009.

15) 久保 晃, 倉本 $\mathrm{A}$ 亜美, 小林 薰·他：理学療法学科 3 押 よび4学年の学習と生活面の満足度変化と国家試験成績. 理学療法科学, 2015, 30: 115-117.

16) 久保 晃, 谷 浩明, 小林 薰. 他: 理学療法学科大学入 学 4 力月後の学習と生活面の満足度. 理学療法科学, 2016, 31: 625-628.

17) 久保晃, 堀本ゆかり, 韓 憲受・他: 理学療法学部生
の学習と生活面の満足度の縦断的調査一 2 年末から卒業ま で一. 理学療法科学, 2017, 32: 709-712.

18）LINEリサーチ：新型肺炎（新型コロナウイルス）に関する 調查結果. https://www.linebiz.com/jp/column/research/corona-virus/?list=13 (閲覧日 2020年 5 月 27 日).

19) 株式会社サーベイリサーチセンター：新型コロナウイルス に関する国民アンケート.https://www.surece.co.jp/wp_surece/wp-content/uploads/2020/03/20200311.pdf（閲覧日 2020 年 5 月 27 日)

20) 藤本純也, 福田一義, 鳥山 稔 - 他 : 大学生への新型コロ ナウイルス感染症拡大の影響 報告書（完成版）. https:// www.kcaa-jp.org/post/20200413 (閲覧日2020年6月 1 日).

21) 静岡県立大学: 新型コロナウイルス感染症拡大とその対策 の静岡県立大学・同短期大学部の学生に対する影響に関す るアンケート集計結果・速報. https://www.u-shizuoka-ken. ac.jp/news/20200512-1/ (閲覧日 2020年6月 1 日).

22) Sasaki N, Kuroda R, Tsuno K, et al.: Workplace responses to COVID-19 associated with mental health and work performance of employees in Japan. J Occup Health, 2020, 62: e12134.

23) Li HY, Cao H, Leung DY, et al.: The psychological impacts of a COVID-19 outbreak on college students in China: a longitudinal study. Int J Environ Res Public Health, 2020, 17: 3933.

24) 国際医療福祉大学: 国際医療福祉大学保健医療学部理学療 法学科 (大田原キャンパス). https://otawara.iuhw.ac.jp/gakubu/rigaku/about-study.html (閲覧日 2020年 7 月 27 日).

25) 株式会社MOCHI:「コロナ禍における就職活動の意識調査」. https://mochi-inc.jp/dl/pdf/02290309.pdf（閲覧日 2020年 8 月 5 日).

26) 松田侑子, 永作 稔, 新井邦二郎: 大学背の就職活動不安 が就職活動に及ぼす影響—コーピングに着目して一，心理 学研究, 2010, 80: 512-519.

27) リクルートキャリア就職みらい研究所：就職プロセス調 査（2021年卒）「2020年6月 1 日時点内定状況」. https:// data.recruitcareer.co.jp/wp-content/uploads/2020/06/naitei_21s-20200605.pdf(閲覧日2020年6月22日).

28) 小野田公, 久保 晃, 丸山仁司: デジタル教材を利用した カードの理学療法分野への効果. 理学療法とちぎ, 2017, 6: $43-46$. 